\title{
Can Allergen Specific Immunotherapy Induce Familial Mediterranean Fever Attacks?
}

\author{
Allerjen Spesifik Immünoterapi Ailevi Akdeniz Ateşi Ataklarını \\ Tetikleyebilir mi?
}

(D) Songül Çildağ, (D) Taşkın Şentürk, (D) Gökhan Sargın

Adnan Menderes University Faculty of Medicine, Department of Immunology-Allergy, Aydın, Turkey

Keywords

Allergen-specific, immunotherapy, Familial Mediterranean Fever

Anahtar Kelimeler

Allerjen spesifik, immünoterapi, Ailesel Akdeniz Ateşi

Received/Geliş Tarihi : 03.08.2015

Accepted/Kabul Tarihi : 14.01.2016

doi:10.4274/meandros.2417

Address for Correspondence/Yazışma Adresi: Songül Çildağ MD,

Adnan Menderes University Faculty of Medicine, Department of Immunology-Allergy, Aydın, Turkey

Phone : +90 5065092753

E-mail : songulcildag@yahoo.com

ORCID ID: orcid.org/0000-0001-9617-0925

(C) Meandros Medical and Dental Journal, Published by Galenos Publishing House.

This is article distributed under the terms of the

Creative Commons Attribution NonCommercial 4.0

International Licence (CC BY-NC 4.0).

\begin{abstract}
Allergen-specific immunotherapy is a treatment aimed to reduce allergic symptoms and need for medication use after exposure to specific allergens. Allergen-specific immunotherapy is the only curative treatment that can change the natural course of allergic diseases. Although, allergen-specific immunotherapy is quite effective in the treatment of atopic dermatitis, allergic asthma, allergic rhinitis, and insect bites, serious treatment-related side effects may still occur. Since allergen-specific immunotherapy can cause changes in the immune system, it is theoretically possible that it can also affect immune system mediated inflammatory diseases such as autoimmune diseases. This is the first case report of an occurrence of Familial Mediterranean Fever attacks during allergen-specific immunotherapy.
\end{abstract}

Öz

Allerjen spesifik immünoterapi kişide spesifik allerjen maruziyeti sonrasında gelişebilecek allerjik semptomları ve ilaç kullanım ihtiyacını azaltmaya yönelik bir tedavi şeklidir. Atopik dermatit, allerjik astım, allerjik rinit ve böcek sokmalarında oldukça etkin bir tedavi şekli olmakla birlikte allerjen spesifik immünoterapi ile ilişkili ciddi yan etkiler de oluşabilmektedir. Allerjen spesifik immünoterapinin, immün sistem üzerinde yapmış olduğu değişiklikler nedeniyle, otoimmün hastalıklar gibi immün sistem aracılığı ile gelişen enflamatuvar hastalık oluşumunu da etkileyebileceği düşünülmektedir. Burada sunduğumuz olgu, allerjen spesifik immünoterapi tedavisi sırasında Ailesel Akdeniz Ateşi atağı semptomları gelişen, bildirilmiş ilk olgu sunumudur.

\section{Introduction}

Allergen-specific immunotherapy (ASIT) is a treatment aimed to reduce allergic symptoms and need for medication use after exposure to specific allergens. The treatment is based on the principle of administration of increasing doses of the allergen. The ASIT has been used in the treatment of allergic diseases for more than a century, and it is the only curative treatment that can change the natural course of allergic diseases (1). The basic objective is to provide peripheral T cell tolerance. Peripheral T cell tolerance is achieved by induction of $\mathrm{T}$ 
regulatory (Treg) cells that are capable of producing anti-inflammatory cytokines such as interleukin (IL)10 and transforming growth factor (TGF)- $\beta$. Treg cells reduce the Thelper (Th) 2 response, in addition to reducing dendritic cell, mast cell, basophil, and eosinophil responses. Moreover, while inducing the production of immunoglobulin (Ig) G4 and IgA, Treg cells regulate an allergen-specific IgE response (2-6). Although, ASIT is quite effective in the treatment of atopic dermatitis, allergic asthma, allergic rhinitis, and insect bites, serious treatment-related side effects may still occur. The ASIT related side effects are divided into two groups: local and systemic side effects. The local side effects include redness, itching and swelling at the injection site, while systemic side effects can range from a mild reaction to life threatening severe anaphylaxis $(7,8)$. Information regarding the long-term side effects of treatment is scarce. Since ASIT can cause changes in the immune system, it is theoretically possible that it can also affect immune system mediated inflammatory diseases such as autoimmune diseases. Sjögren's syndrome, multiple sclerosis, localized scleroderma, recurrent pericarditis and vasculitis have all been reported to occur during ASIT. This present case is the first report of an occurrence of Familial Mediterranean Fever (FMF) attacks during ASIT.

\section{Case Report}

A 34-yr-old female patient was admitted to our clinic for continuation of her treatment. She had been treated for allergic rhinitis, using the grass pollen antigens group conventional immunotherapy treatment, for 3.5 years in another clinic. Based upon the patient's medical history, we learned that in the beginning the second year of her immunotherapy significant clinical response was achieved; the patient no longer required treatment with antihistamines. However, we learned that 4 months ago the patient was diagnosed with FMF. The patient reported no family history of FMF. Her complaints started 6-7 months ago, with once a month abdominal pain attacks lasting 3-4 days, accompanied by fever. Fever ranging from 38-39 degrees Celcius and there was diffuse abdominal pain. Abdominal attacks were not associated with menstruation. She had no contraceptive ring. The physician from the initial clinic that the patient presented to diagnosed her with
FMF and initiated a $1.5 \mathrm{mg} /$ day colchicine treatment. The colchicine treatment gave a dramatic response. Genetic testing did not detect any mutations consistent with FMF for E148Q, M680I, M694V, V726A, F479L, A744S, R761H. The patient's physical examination performed in our clinic was normal. Moreover, her complete blood count, sedimentation rate, C-reactive protein, liver function tests, kidney function tests, urinalysis, and anti-nuclear antibody levels were within the normal limits. The patient had been undergoing ASIT treatment for 3.5 years and experienced a significant improvement of her symptoms. The onset of FMF had started during this treatment period and since the patient did not have a family history FMF, we suggest that the FMF attacks may have been triggered by ASIT. For this reason, and also because the immunotherapy completed its 3.5year course, we decided to terminate the patient's immunotherapy and closely follow-up the patient.

\section{Discussion}

Although short-term local and systemic side effects of ASIT are known, long-term side effects are not well known (9). There are publications that suggest that ASIT treatment could cause the development of autoimmune diseases. Sjögren's syndrome, multiple sclerosis, scleroderma, pericarditis and vasculitis are among such reported autoimmune diseases (913). However, no publications exist in the literature with regard to a link between ASIT applications the development FMF attacks. ASIT is the only curative treatment for allergic diseases. It causes the induction of allergen-specific Treg cells that produce IL-10 and TGF- $\beta$. This induction results in a B cell increase in the production of $\operatorname{IgG} 4$ and $\operatorname{IgA}$, with a decrease in the production IgE. The ASIT stimulates immunosuppressive Treg cells and shifts the Th1-Th2 balance towards Th1 by partially increasing the activity of suppressor $\mathrm{T}$ lymphocytes. It was determined that while the secretion of cytokines such as IL-4, IL-5, IL9, IL-13, tumor necrosis factor (TNF)- $\alpha$ and IL- 1 from Th2 cells decreases, the synthesis of cytokines such as IL-2, IL-12, IL-18, IFN- $\gamma$ and TNF- $\beta$ by Th1 increases, therefore changing the cytokine profile of T cells. In addition, the production of TGF- $\beta$, as a result of Treg cell induction, increases the differentiation of Th17, which is thought to be associated with autoimmune diseases (11,14-16). FMF is a disease characterized 
by abdominal pain, chest pain or joint pain caused by inflammation in one or several of the following: peritoneum, pleura or synovial serous membranes. The course of FMF attacks is accompanied by fever. The attacks are self-limiting, lasting for 1-3 days, and heal spontaneously if left untreated. In $70 \%$ of the patients, symptoms appear in the first decade of life, while in $90 \%$ of them they are observed in the first two decades of life (17-19). FMF is a common disease in communities originating from the Eastern Mediterranean, particularly Jews, Turks, Armenians and Arabs. However, the disease has been diagnosed even in Japanese patients (20). The carrier frequency in Turkish, Armenian and Jewish populations were detected at high levels such as $1 / 3-1 / 5(21,22)$. The disease-causing gene (MEFV) encodes for a protein called pyrin also known as marenostrin (Marenostrum: Mediterranean). In healthy individuals, under normal conditions, pyrin plays a role in controlling inflammation. Mutations in this gene may result in the inability of pyrin to perform its function, thus leading to deterioration of the control of inflammation $(23,24)$. The inflammatory response caused by minor trauma in the joints and by stress, which is induced by variety of cytokines, are inhibited in the presence of normal pyrin, however in patients with FMF it is thought that mutant pyrin is not able to control the inflammatory response (25). Wide expression of pyrin in mature neutrophils suggests that this protein may provide down regulation of the inflammation mediators $(26,27)$. Since neutrophils are the main cells of the acute inflammatory process, mutated pyrin's inability to perform its function may lead to the uncontrolled activation of neutrophils and cause the migration of these cells to serosal tissue (28). The emergence of attacks due to stress, the onset of attacks with metaraminol infusion and the response to colchicine treatment suggest that a defect in the metabolism of catecholamines may be involved in the pathogenesis of FMF (29). Today, the most widely accepted opinion on the pathogenesis of the disease is that a deficiency of C5a inhibitor, which is an inhibitor quite strong granulocyte chemoattractant $\mathrm{C} 5 \mathrm{a}$, may cause an acute inflammatory attack (30). It is also thought that the presence of pyrin increases the synthesis of $\mathrm{C} 5 \mathrm{a}$ / IL-8 inhibitory factor, while in patients with FMF the C5a/IL-8 inhibitory factors are deficient (31). There was no MEFV mutation and no family history of FMF in our patient, which suggests a sporadic case of FMF. Since the patient's symptoms manifested silently, we hypothesize that the FMF attacks developed due to the changing immune response as a result of ASIT treatment. In addition, the patient was asymptomatic for allergic rhinitis; therefore, we terminated the patient's treatment. One reason that ASIT treatment may trigger FMF attacks is by inciting a shifting in the direction of Th1/Th2 balance towards the Th1, with a subsequent increase in the serum IL-17 levels, which has an important role in the etiopathogenesis of autoimmune diseases. In patients with FMF, serum IL-17 levels were high both during the attack one of the autoinflammatory disease periods and during asymptomatic periods (32). During FMF attacks, IL-17 plays an important role in the activation of neutrophils, predominant cells at the serosal surfaces. In addition, it stimulates the maturation, migration and function of neutrophils. Moreover, IL-17 ensures the migration of neutrophils to the peritoneal cavity during the attack period $(33,34)$. In our case, we think that the increase of IL-17 levels induced by the ASIT treatment may have triggered the FMF attacks. But we did not find any data on this subject in the literature. So, we think that this issue should be investigated.

\section{Ethics}

Informed Consent: Informed constent was not taken because there was no information sharing involving personal data.

Peer-review: Externally and internally peerreviewed.

\section{Authorship Contributions}

Surgical and Medical Practices: S.Ç., T.Ş., Concept: S.Ç., T.Ş., G.S., Design: S.Ç., T.Ş., G.S., Data Collection or Processing: S.Ç., T.Ş., G.S., Analysis or Interpretation: S.Ç., T.Ş., G.S., Literature Search: S.Ç., T.Ş., G.S., Writing: S.Ç., T.S.., G.S.

Conflict of Interest: No conflict of interest was declared by the authors.

Financial Disclosure: The authors declared that this study received no financial support.

\section{References}

1. Bousquet J, Lockey RF, Malling HJ. Allergen immunotherapy: therapeutical vaccines for allergic diseases A WHO Position Paper. Allergy 1998; 53(Suppl 54): 1-15.

2. Akdis CA, Akdis M. Mechanisms of allergen-specific immunotherapy. J Allergy Clin Immunol 2011; 127: 18-27. 
3. Gri G, Piconese S, Frossi B, Manfroi V, Merluzzi S, Tripodo C, et al. $\mathrm{CD} 4+\mathrm{CD} 25+$ regulatory $T$ cells suppress mast cell degranulation and allergic responses through OX40-OX40L interaction. Immunity 2008; 29: 771-81.

4. Kearley J, Barker JE, Robinson DS, Lloyd CM. Resolution of airway inflammation and hyperreactivity after in vivo transfer of CD4+CD25+ regulatory T cells is interleukin 10 dependent. J Exp Med 2005; 202: 1539-47.

5. Kearley J, Robinson DS, Lloyd CM. CD4+CD25+ regulatory T cells reverse established allergic airway inflammation and prevent airway remodeling. J Allergy Clin Immunol 2008; 122: 617-24.

6. Meiler F, Klunker S, Zimmermann M, Akdis CA, Akdis M. Distinct regulation of IgE, IgG4 and IgA by T regulatory cells and toll-like receptors. Allergy 2008; 63: 1455-63.

7. Cox L, Larenas-Linnemann D, Lockey RF, Passalacqua G. Speaking the same language: The World Allergy Organization Subcutaneous Immunotherapy Systemic Reaction Grading System. J Allergy Clin Immunol 2010; 125: 569-74.

8. Jacobsen L, Niggemann B, Dreborg S, Ferdousi HA, Halken S, $\mathrm{H} \varnothing \mathrm{st} A$, et al. Specific immunotherapy has long-term preventive effect of seasonal and perennial asthma: 10-year follow-up on the PAT study. Allergy 2007; 62: 943-8.

9. Turkcapar N, Kinikli G, Sak SD, Duman M. Specific immunotherapy induced Sjögren's syndrome. Rheumatol Int 2005; 26: 182-4.

10. Nakajima H, Ohtsuka S, Nishina T, Sugino M, Kimura F, Hanafusa $T$, et al. Multiple sclerosis after allergen-specific immunotherapy and influenza vaccination. Eur Neurol 2003; 50: 248-9.

11. Morfin Maciel BM, Castillo Morfin BM. Scleroderma realted to specific immunotherapy. A report of a case. Rev Alerg Mex 2009; 56: 136-45.

12. Quirce S, Fernandez Rivas M, Losada E, de la Hoz B, Fraj J, Alvarez Cuesta E. Recurrent pericarditis: a rare complication of allergen immunotherapy. Allergy 1992; 47: 343-5.

13. Phanuphak $P$, Kohler PF. Onset of polyarteritis nodosa during allergic hyposensitization treatment. Am J Med 1980; 68: 47985.

14. Wing K, Sakaguchi S. Allerjide potansiyel immünoterapi için regülatör T hücreler. Curr Opin Allergy Clin Immunol 2006; 1: 4.

15. Akdiş CA, Blaser K. IL-1 induced anergy in peripheral T cell and reactivation by. T Klin J Allergy-Asthma 2000; 2: 42-4.

16. Larche M. Regulatory T cells in allergy and asthma. Chest 2007; 132: 1007-14.

17. Sohar E, Gafni J, Pras M, Heller H. Familial Mediterranean fever. A survey of 470 cases and review of the literature. Am J Med 1967; 43: 227-53.

18. Akarsu AN, Saatci U, Ozen S, Bakkaloglu A, Beşbaş N, Sarfarazi M. Genetic linkage study of familial Mediterranean fever (FMF) to $16 \mathrm{pl} 3.3$ and evidence for genetic heterogeneity in the Turkish population. J Med Genet 1997; 34: 573-8.

19. Amyloidosis FMF and MEFV gene. Amyloid: Int J Exp Clin Invest 2000; 7: 289-93.
20. Gershoni-Baruch R, Shinawi M, Leah K, Badarnah K, Brik R. Familial Mediterranean fever: prevalence, penetrance and genetic drift. Eur J Hum Genet 2001; 9: 3-7.

21. Yilmaz E, Özen S, Balci B, Duzova A, Topaloglu R, Besbas N, et al. Mutation frequency of familial mediterranean fever and evidence of a high a carrier rate in the Turkish population. Eur J Hum Genet 2001; 9: 553-5.

22. Yazıcı H, Özdoğan H. Familial Mediterranean fever in Turkey. In: Sohar E, Gafni J, Pras M, eds. Proceeding of the I. International Conference on FMF, Tel Aviv: Freund; 1997.p.66-71.

23. Eisenberg S, Aksentijevich I, Deng Z, Kastner DL, Matzner J. Diagnosis of Familial Mediterranean Fever by a Molecular Genetics Method. Ann Int Med 1998; 129: 243-51.

24. Pras M. Familial Mediterranean fever: from the clinical syndrome to the cloning of the pyrin gene. Scand J Rheumatol 1998; 27: 92-7.

25. Goldfinger SE. Colchicine for Familial Mediterranean Fever. New Eng J Med 1972; 287: 1302.

26. No authors listed. Ancient missense mutations in a new member of the RoRet gene family are likely the cause familial Mediteranean fever. The International FMF Consortium. Cell 1997; 90: 797-807.

27. Ben-Chetrit E, Levy M. Familial Mediterranean fever. Lancet 1998; 351: 659-64.

28. Notarnicola C, Didelot MN, Kone-Paut I, Seguret F, Demaille J, Toitou I. Reduced MEFV messenger RNA expression in patient with familial Mediterranean fever. Arthritis Rheum 2002; 46: 2785-93.

29. Barakat MH, Malhas LN, Gumaa KK. Catecholamine metabolism in recurrent hereditary polyserositis. Pathogenesis of acute inflammation: The retention leakage hypothesis. Biomed Pharmacother 1989; 43: 763-9.

30. Matzner Y, Ayesh SK, Hochner-Celniker D, Ackerman Z, Ferne $M$. Proposed mechanizm of inflammatory attacks in familial Medeterranean fever. Arch Intern Med 1990; 150: 1289-91.

31. Direskeneli H, Ozdogan H, Korkmaz C, Akoglu T, Yazici H. Serum soluble intercellular adhesion molecule-1 and interleukin 8 levels in Famial Mediterranean Fever. J Rheumatol 1999:26.

32. Haznedaroglu S, Oztürk MA, Sancak B, Goker B, Onat AM, Bukan $\mathrm{N}$, et al. Serum interleukin 17 and interleukin 18 levels in familial Mediterranean fever. Clin Exp Rheumatol 2005; 23 (4 Suppl 38): 77-80.

33. Schwarzenberger P, La Russa V, Miller A, Ye P, Huang W, Zieske A, et al. IL-17 stimulates granulopoiesis in mice: use of an alternate, novel gene therapy- derived method for in vivo evaluation of cytokines. J Immunol 1998; 161: 6383-9.

34. Witowski J, Pawlaczyk K, Breborowicz A, Scheuren A, KuzlanPawlaczyk M, Wisniewska J, et al. IL-17 stimulates intraperitoneal neutrophil infiltration through the release of GRO alpha chemokine from mesothelial cells. J Immunol 2000; 165: 581421. 